$3 \times a 4$

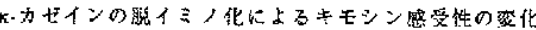

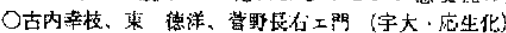

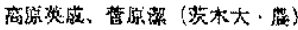

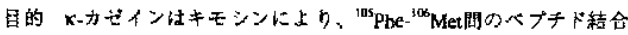

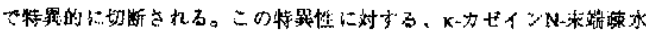

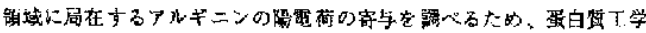

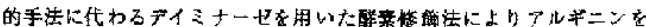

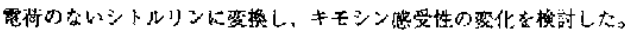

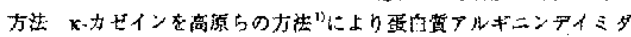

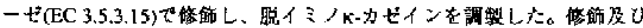

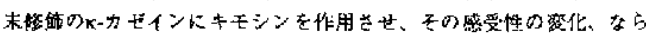
ひに切断部位の变化についてSDS-PAGEに上り解析しだ。

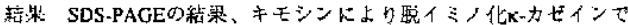

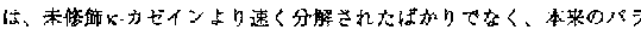

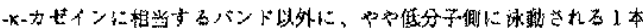

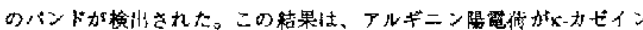

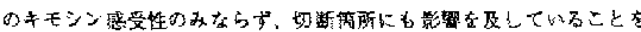

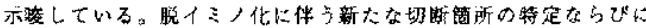

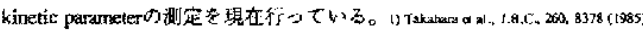

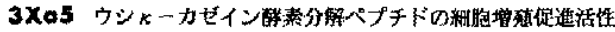

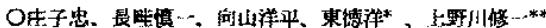

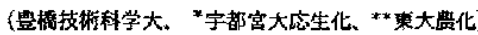

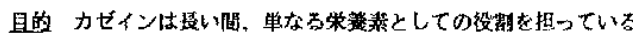
と考えられていたが、近年、カぜイン及びモの消化ペブチドに生理

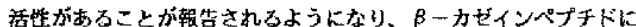

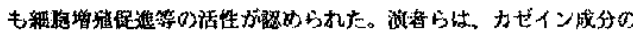

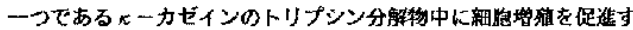
る活性因手の存在を梌索することを目的とした。

方法 Zittleらの方法上り得られた粗

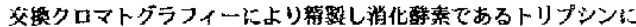

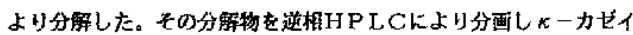

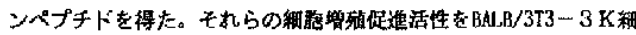

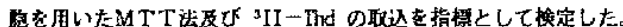

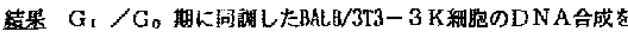
槅遭するいくつかの

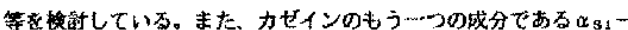

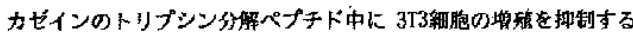
ペプチドの存在が示嗦された。

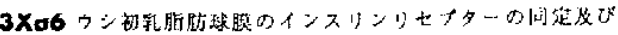
インスリン䊅合性

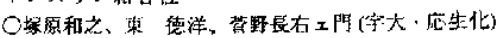

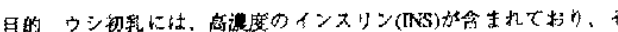

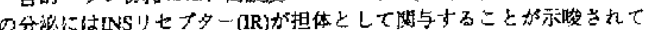

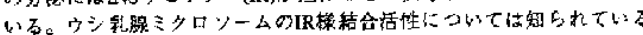

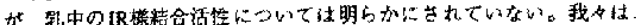

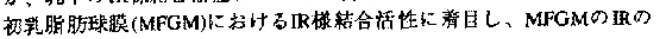

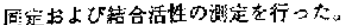

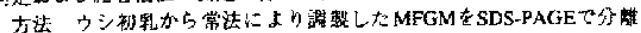

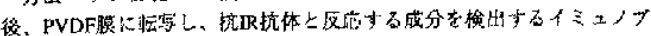

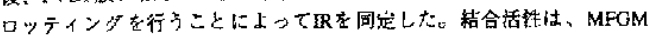

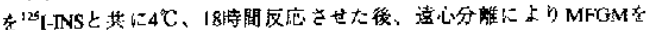

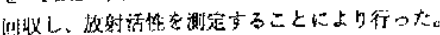

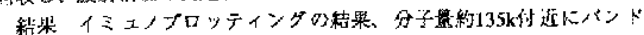

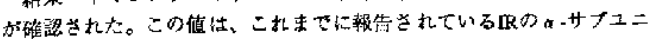

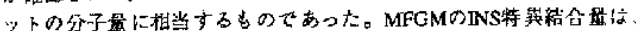

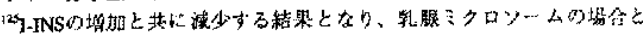

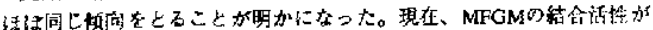

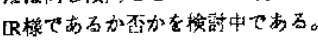

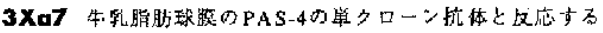
木エ一阿分中り成分り特性门空甫 植、金 東影*

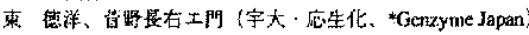

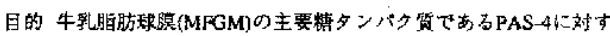
る単クローン抗体を作成し、これと反応するホエー面分中のダンバン

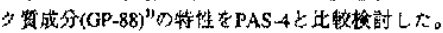

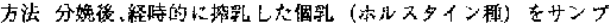

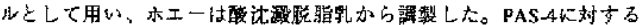
単クローン杭体(KAS4)を作成し、これを用いててELISA坑よびイミュ，

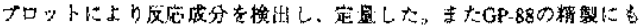
KASAを用以た。

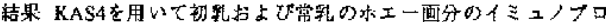

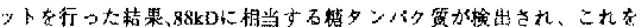

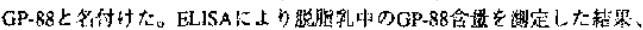

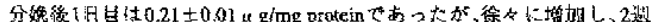

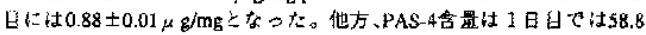

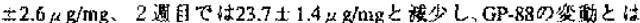

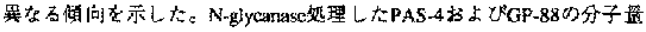

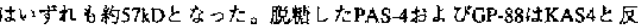
応すること加ら、モの土ビトーブがパチドであると推溉光机、現在同

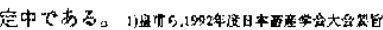

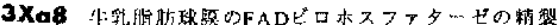

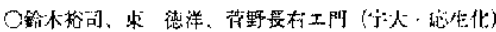

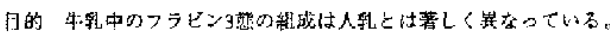

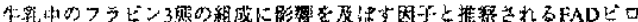
ホスファターセ（FADase）が牛乳脂肪球滕（MFGM）に局在している

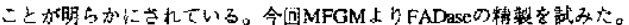

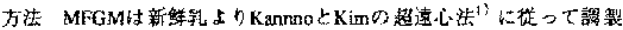

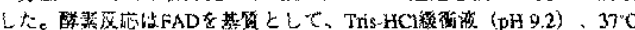

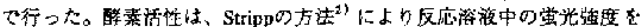
程定し、生成したFMN得で示した。

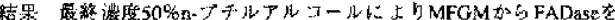

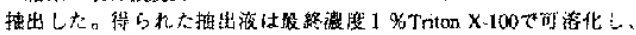

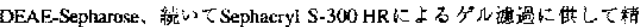

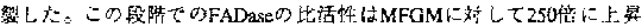

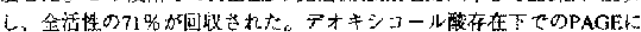

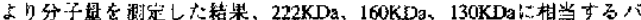

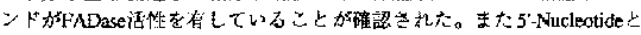
㩆合させたをこちADPは30\%、AMPは35\%、TrPは43\%、UTPは21\%の FADax活性汃相密究九た。

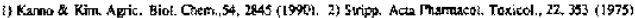

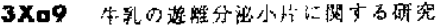

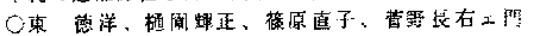
(宇大·岓生化)

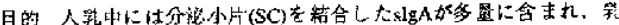

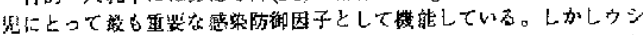

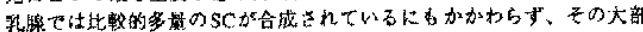

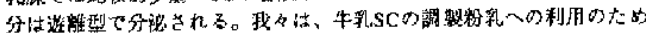

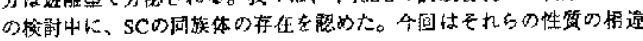
について報装する。

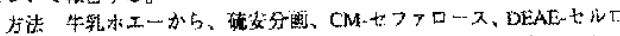

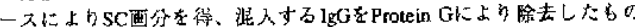

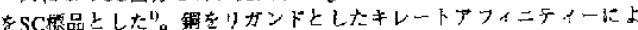

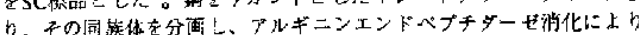

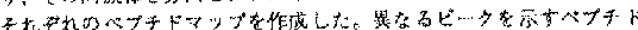

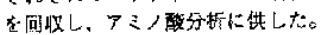

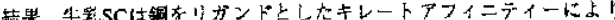

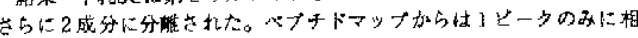

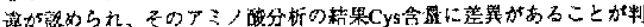

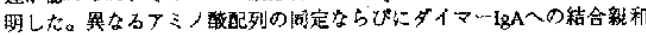

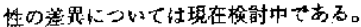

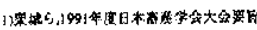




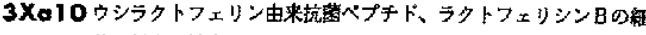
圈に対す結合について

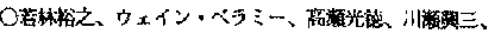

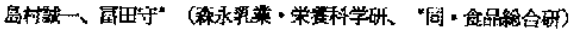

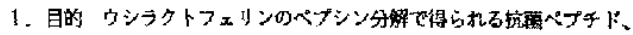

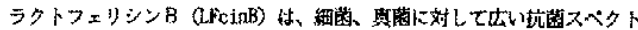

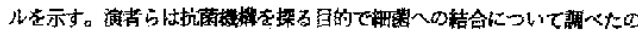
で報告する。

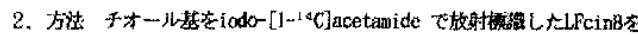

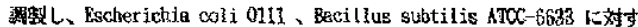

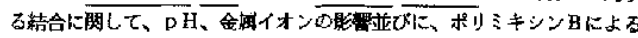

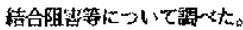

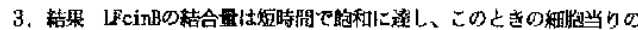

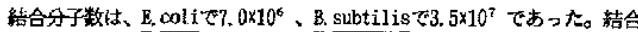

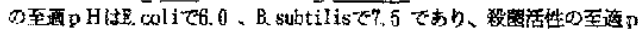

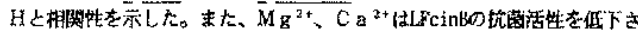

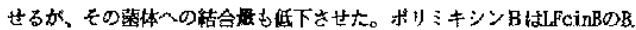

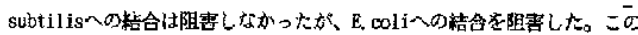

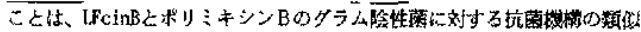
惟を示物している。

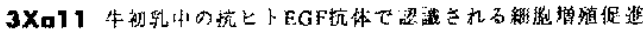

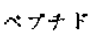

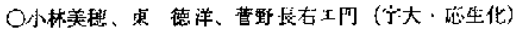

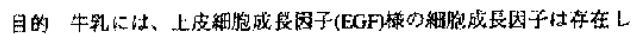

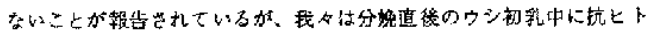

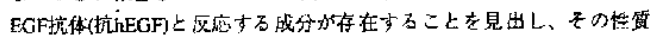

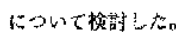

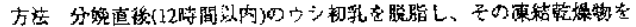

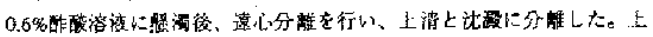

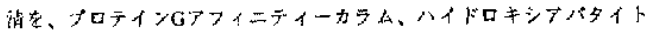

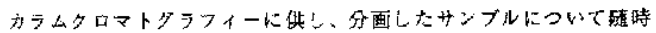

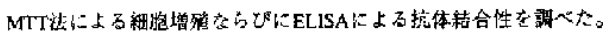

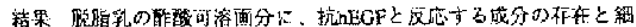

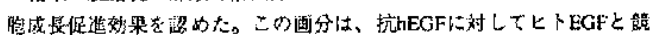

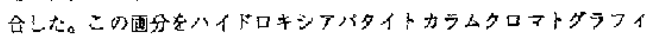

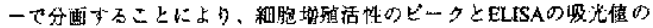
ビークと加教することを明ら加にした。この成分について现在更に 精製を進的ている。

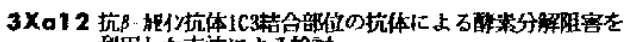
利用した方法による䛈部

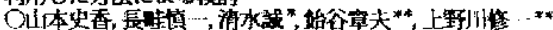

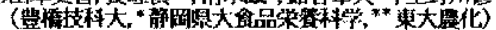

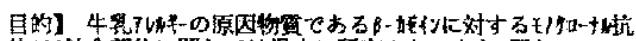
体1C3赫合部位に関しては渴去に研究されてきた。即ちConpet

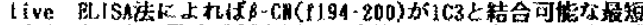

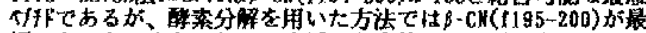

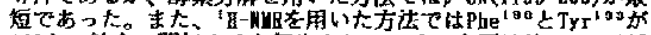

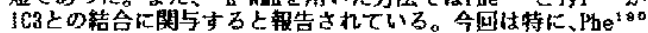

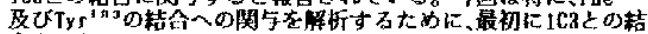

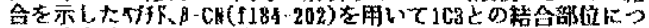

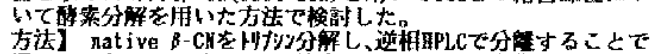
得た

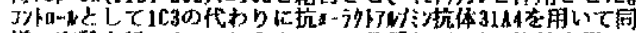

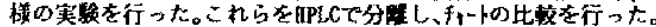

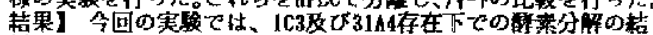

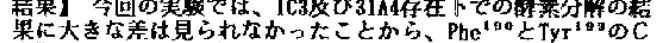

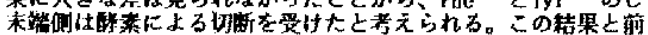

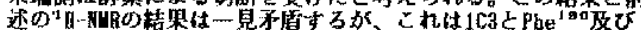

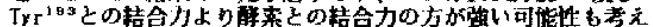

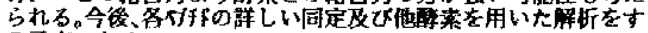
予定である。

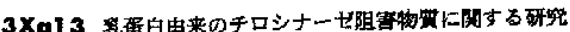

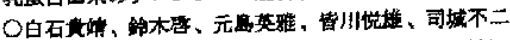

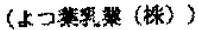

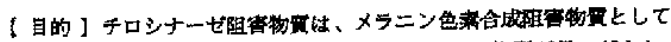

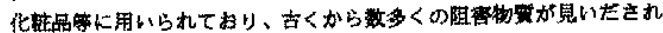

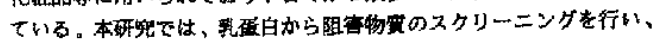

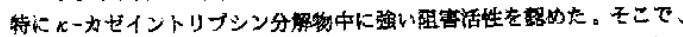

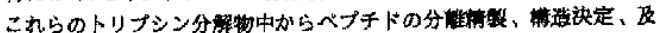

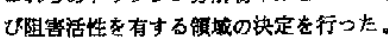

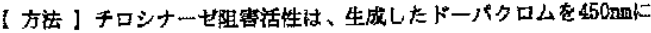

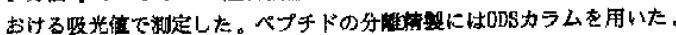

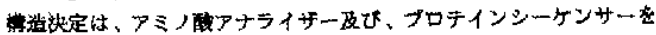

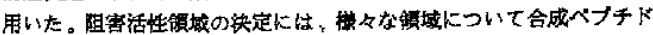

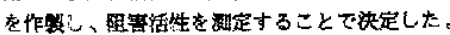

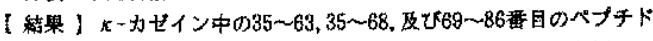
ヒチロシナーゼ阻害活姓が㽝められた。また、合成ペブチドを男いた

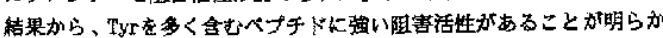

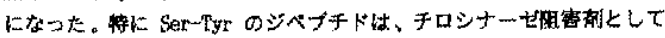

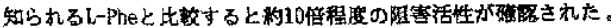

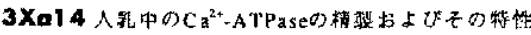

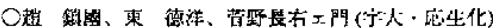

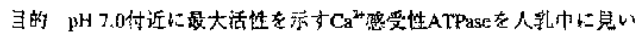

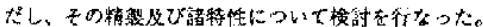

方法上ト成柇より調繁したハターミルク画分を2\% Tween 20 で抽 出L、 20 可塎性西分加 D DEAE-Sepharose, Con A . Hi-L osad Superdex

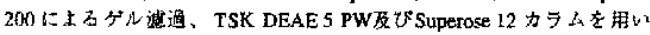

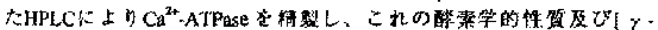
${ }^{32}$ P|ATPによるリン酸化中間体の形成を調へた。

籍果 $\mathrm{Ca}^{2+}$-ATPaseはバターミルタ画分の比活性の約110倍にまで精

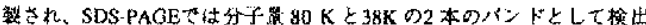

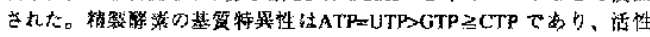

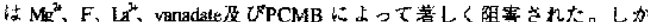

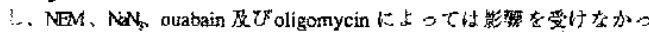

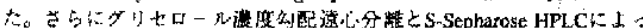

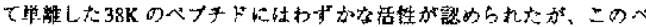

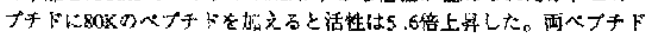

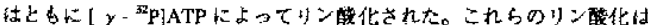
$1 \mathrm{mM} \mathrm{MgCl}$ \& varadaleによって䧋整岂九た。

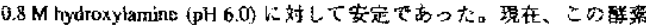

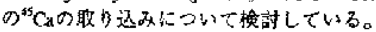

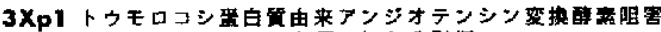

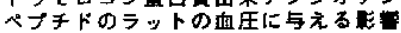

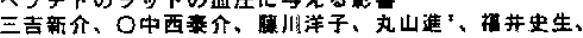

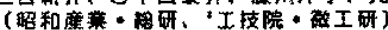

1. 目的トゥモロコシ蛋白页やイキジク濑波から睍いだしたアンジ

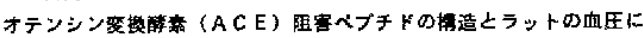

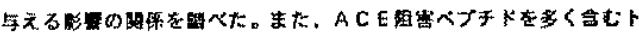

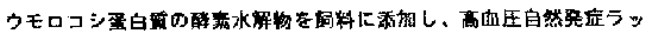

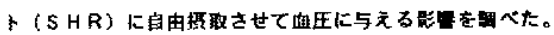

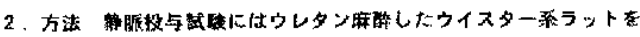

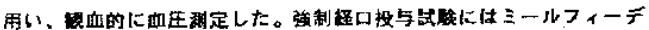

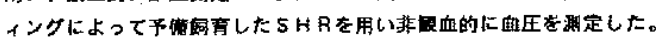

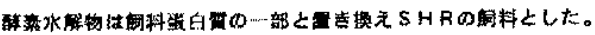

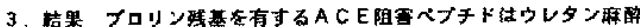
ラットにおけるアンジオテンシンにによる界压を效果的に抑制し、

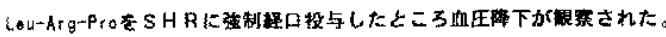

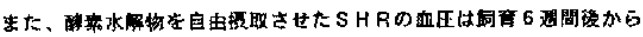

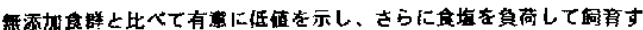

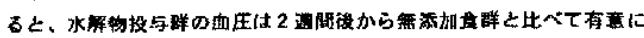

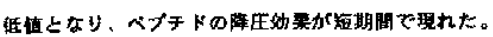


3Xp2 高極性ACE阻害ペプチト

○松藤 赛、热井 利郎、*関 英治、*筬島 克㭲、

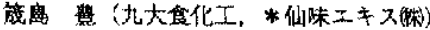

[目的】高血压予防の一助として注目されているACE阳害ペナ

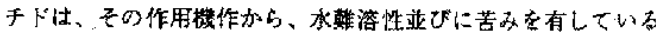

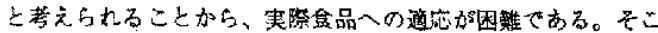
で今回演者らは高活性でがつ無釉無奥の画分上り新規ACE阻害 ベプチドを単離したので報告する。

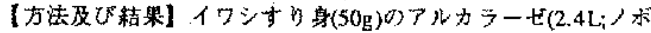

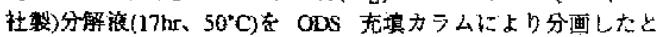

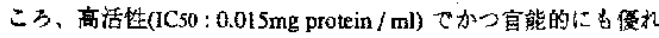

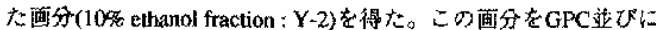
逆相クロマトグラフィーを繰り这すことにより、新规ACE隆害

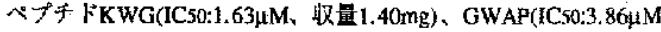
$0.11 \mathrm{mg}) 、 \mathrm{GRP}(\mathrm{ICs} 0: 20.0 \mu \mathrm{M} 、 0.99 \mathrm{mg}) 、 \mathrm{MF}(1 \mathrm{C} 50: 44.7 \mu \mathrm{M}$ 、 $3.50 \mathrm{mg}) 、 \mathrm{RFH}(\mathrm{ICs0}: 330 \mu \mathrm{M} 、 6.88 \mathrm{mg})$ を単離した。中でも $\mathrm{KWC}$ は最る话生加高く、C末端加Giyでるという今まで赫告例の ないペプチドであった。また、他のべプチドは、金て新替配列 を有したべブチドであった。

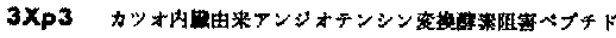

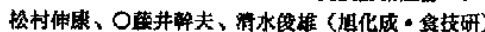

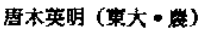

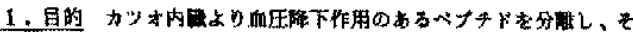

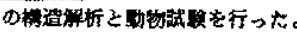

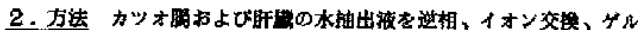

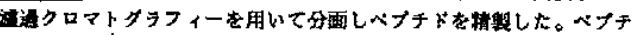

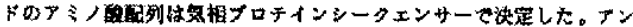

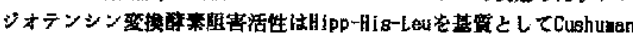

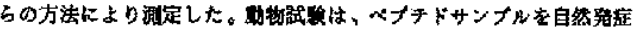

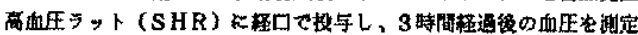
することにより行った。

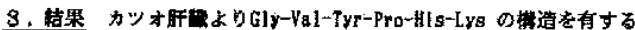

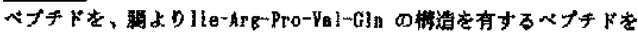

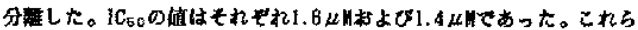

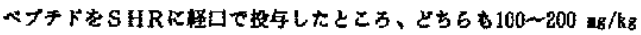

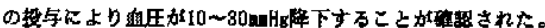

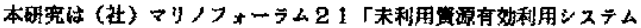
研究会」の研究の一部として行われた。

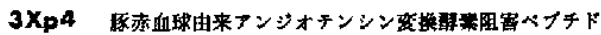

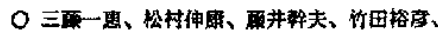

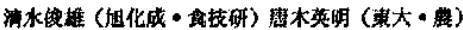

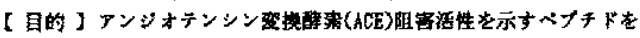

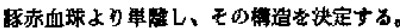

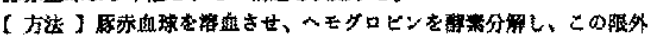

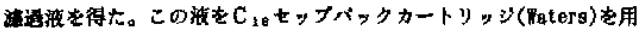

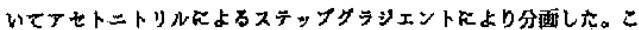

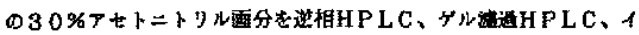

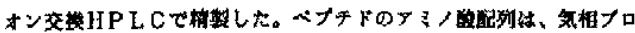

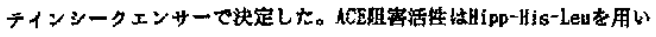

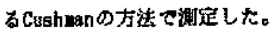

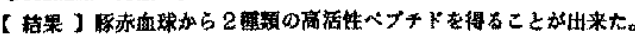

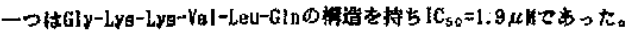

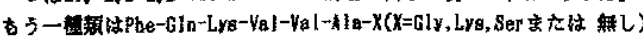

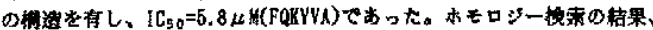

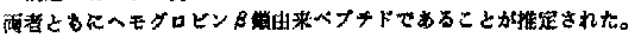

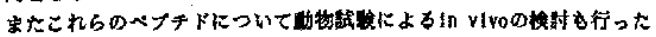
ので台わせて報告する。

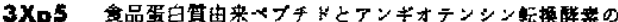
相页作用吉川正明、传々梌、

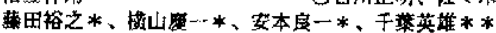

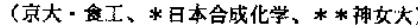

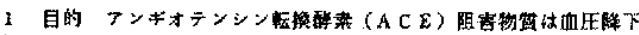

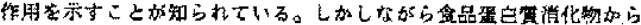
得られだブチドの1n vitroでのAC E 阻窨活性と経口投与の際の血

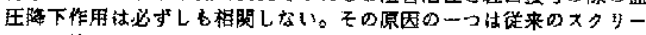

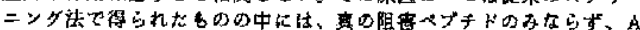

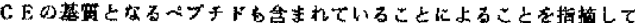

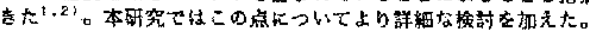

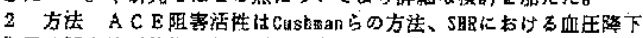

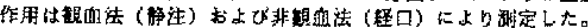

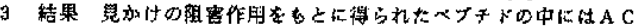

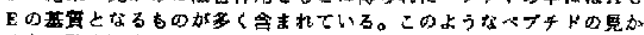

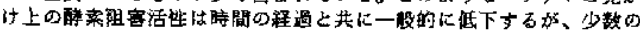

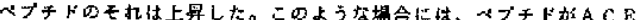

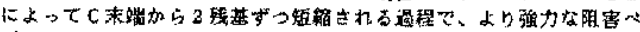
プチドが生成立ること加判明した。ACEにより分解され、見加け上

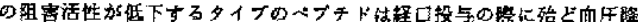

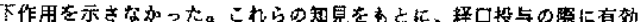

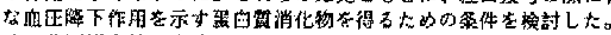

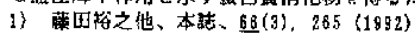

2) Yokoyama, K. et al.. "Peptide Chemistry 1992" in press

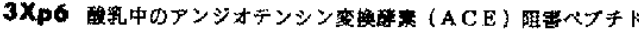

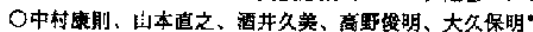

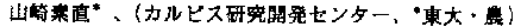

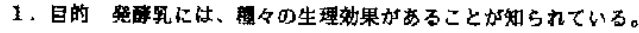

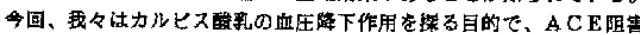

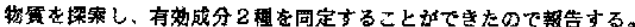

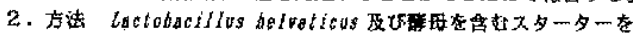

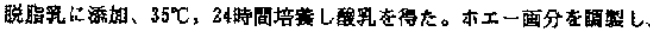

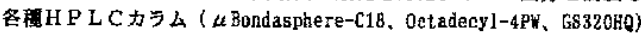

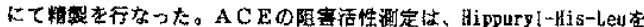

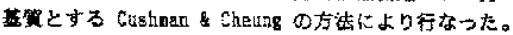

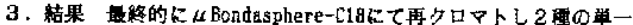
ピークを很た。NMR，アミノ酸組成，アミノ酯シークエンス分析の

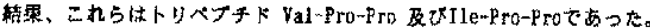

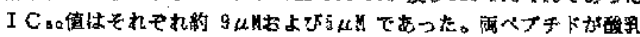

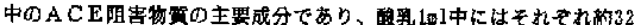

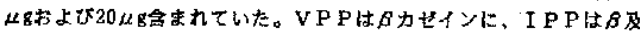

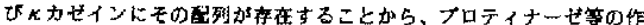
用によ口カぜインから生成するものと推軏された。

3Xp7 大豆由来低分子ベフチドのinvitraにおける ACE助客活 情について

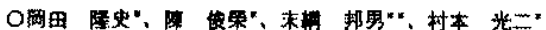

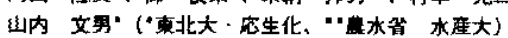

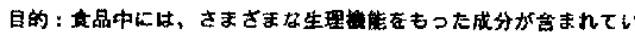

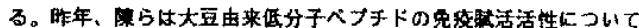

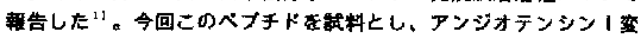

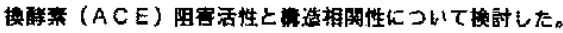

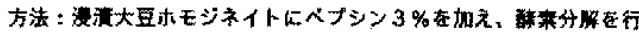

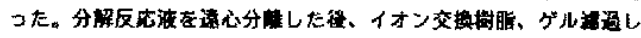

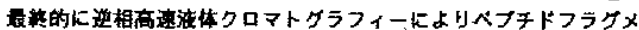

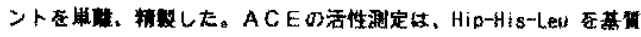
としてCheungらのち法により行つた。

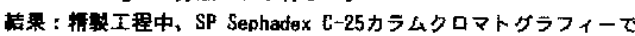

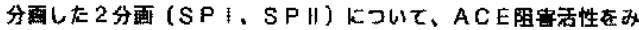

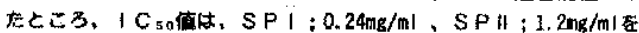
示した。更にSPI分爾を高速浓体クロマトグラフィー纸てベブ

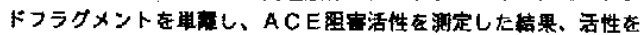

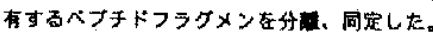

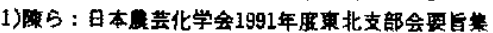




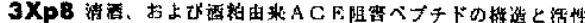

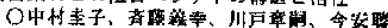

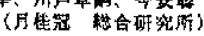

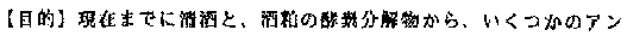

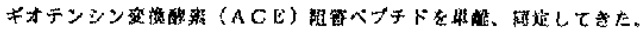

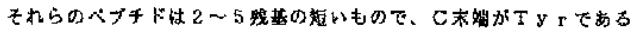

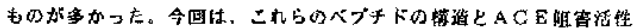

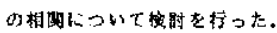

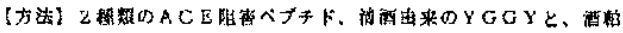

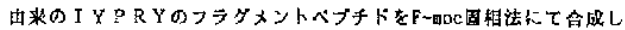

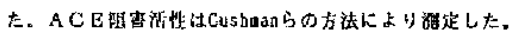

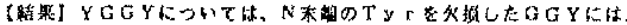

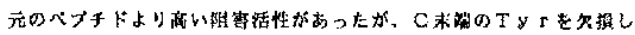
た YGGに性、棌とんど阻害结性がなかった。

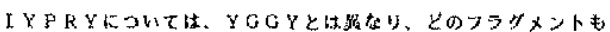

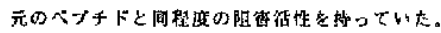

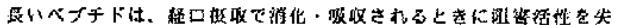

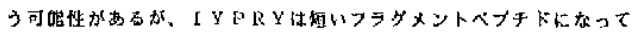

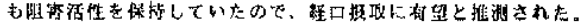

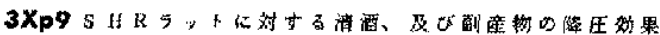
(月偖解稑合研究所)

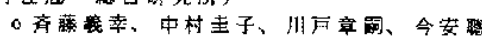

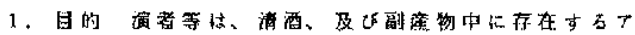

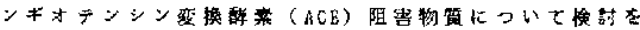

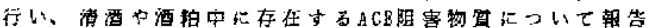

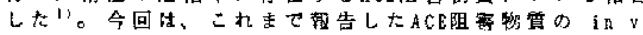
门

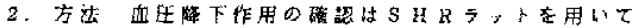

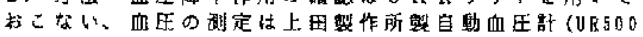

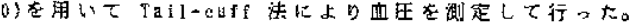

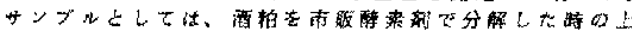

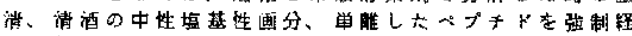

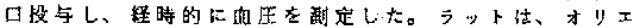

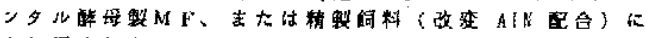
より垌㖹した。

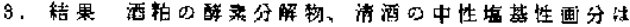
$1 \mathrm{~g} / \mathrm{kg}$ の投与飞有意极血匠洛下作用を亦した。

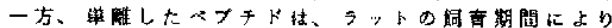

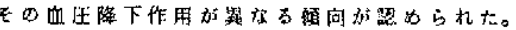

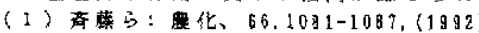

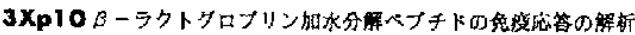

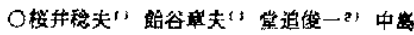

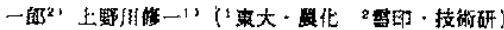

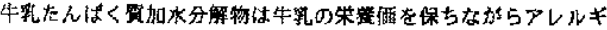

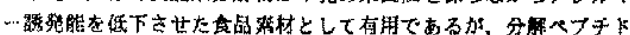

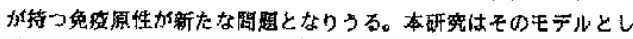

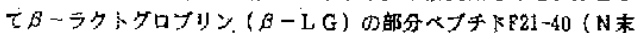

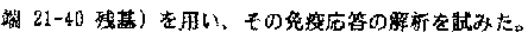

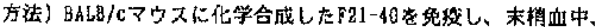

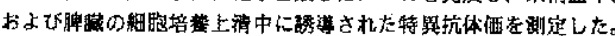

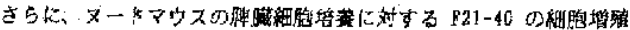

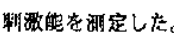

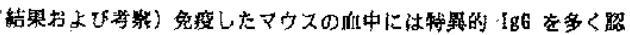

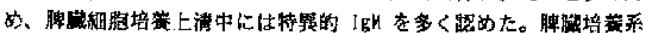

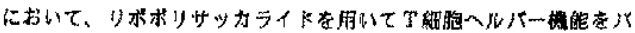

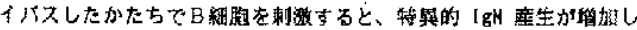

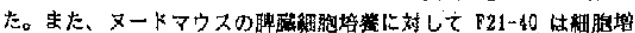

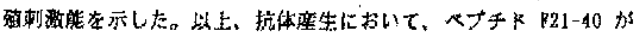

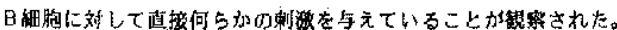

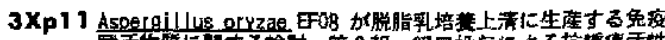

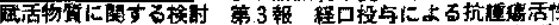

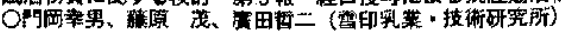

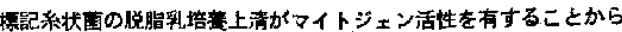

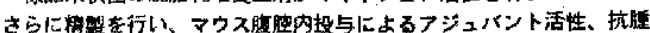

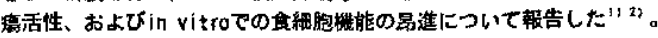

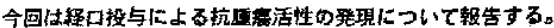

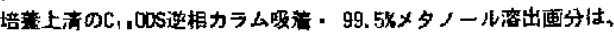

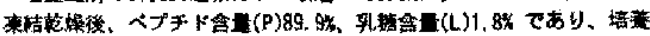

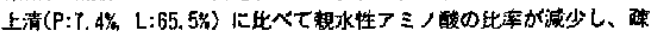
水性アミノ形の比率か増加した。その画分を、マウス 1匹むたり1日 $10 \mathrm{mg} 00.2 \mathrm{ml}$ の30\% 䭪黄溚洨”に溶解し、了 日間カテーテルで経口投

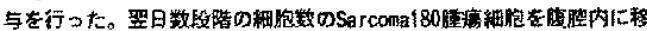

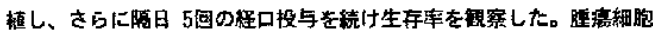

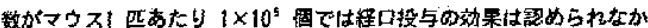

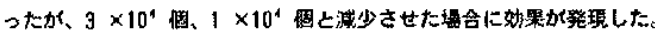

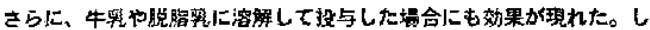

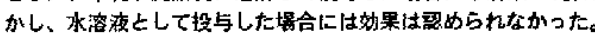
1)Fuj iwara et al.: J. Agric. Food Chem, 40(7), 1280\{1892\}

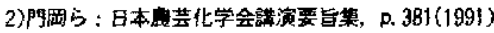

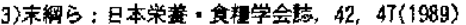

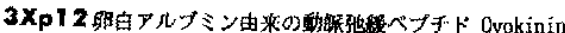

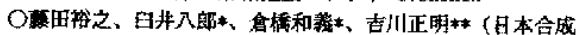

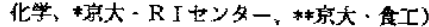

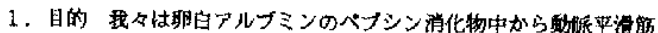

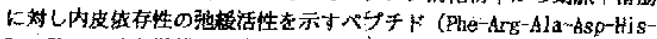

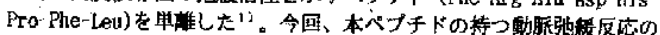

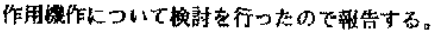

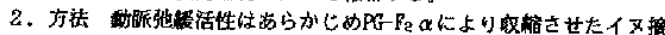

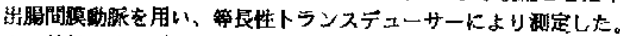

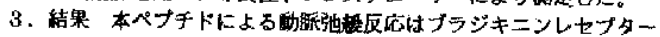

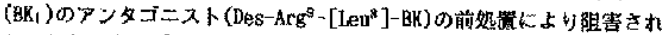

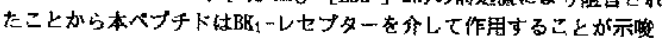
された。本べブチドを"Uvokinin"と郃名した。さらた、N0 synthaseの

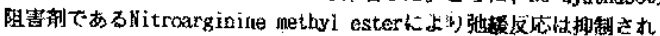
なかったが、Cyclooxygenaseの教害剂である Aspirin、Indomethacin

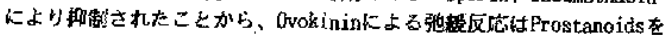
介したものであることが示脸された。なお、ここで関与する Prosta

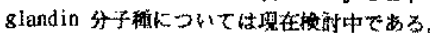

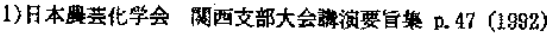

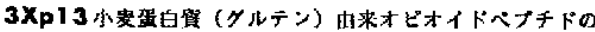

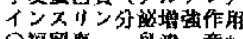

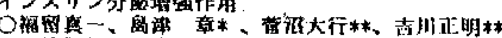

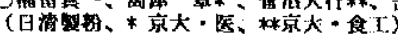

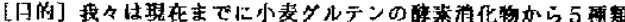

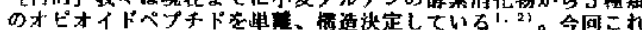

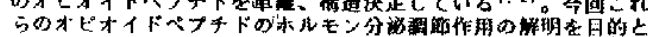

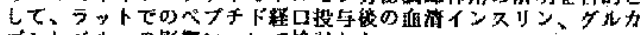
コンレヘルのの影零について馀詩し。

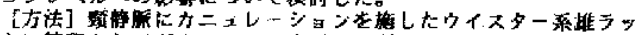

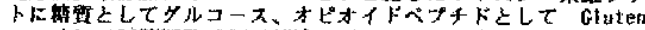

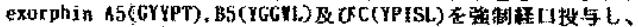

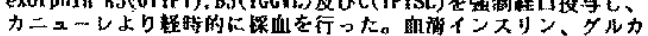

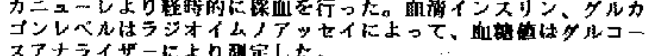

スアナライサー比破定L大。

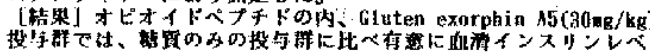

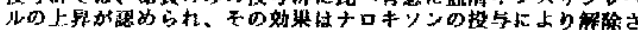

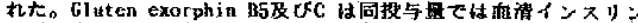

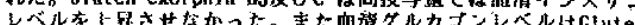

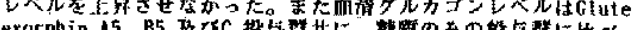

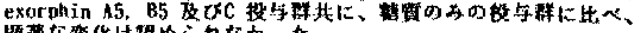

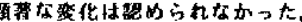

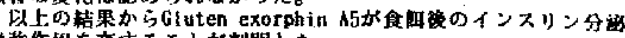
增被作猢を有することが判明した。

1) S. Fukudowe, and Y. Yoshikaws. FRBS lett, 298. 107(1992) 2) S. Fukudone, and N. Yoshikava, FEBS Lett., in press. 
3Xp14小表グルテンから派生するファコササイトーシス促進ベプチド

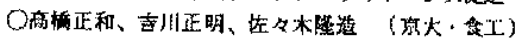

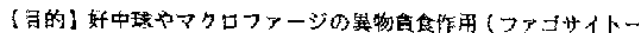

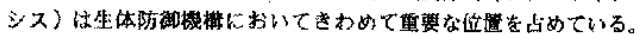

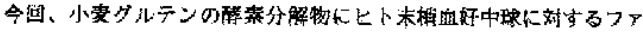

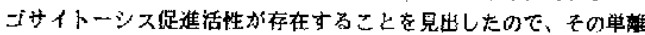

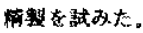

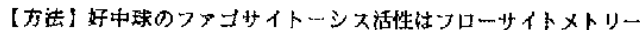

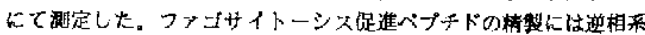
カラムを用い、HFLCにて行なった。

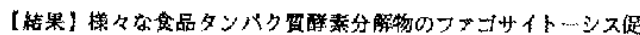

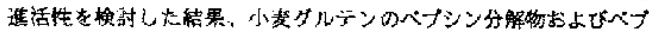

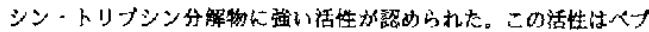

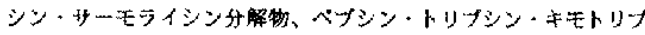
シン分解物にははとんど祸められなかったことから、その活性本体 はベフチドであると考えられた。熶白强い活性を示したベすシン。

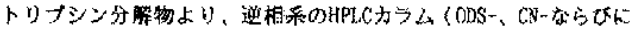

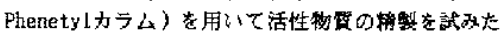

\section{Xp15グルタセレノンジアステレオマーによるダルタチオン ベルオキシターせ度志}

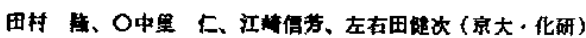

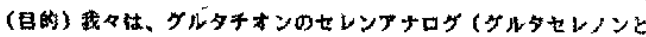

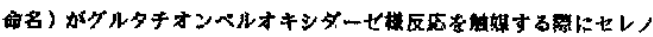

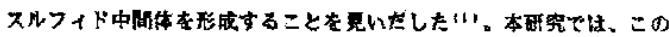
タルタチオンとタルタセレノンとのセレノスルフィド体はるダルタ

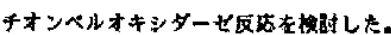

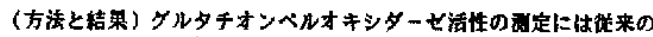

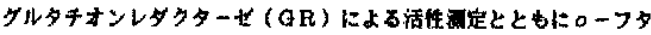

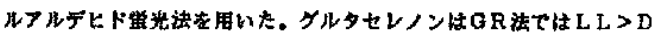

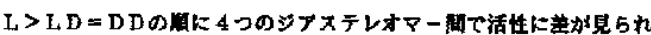

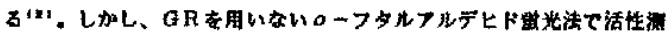

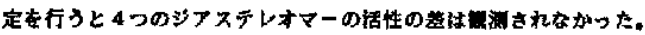

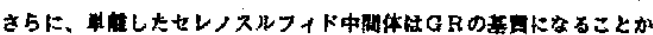
5、GRの作用により、シフステレオマー即でグタチオンルルオキ シターせ洁性の塞が生ず石と教えられる。

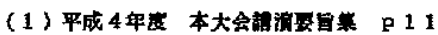

(2) 生化陆 63 671 (1991)

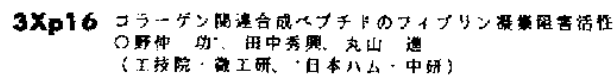

[目的]トロンピンの作用によりフィンリノーヂンがィフリノメ

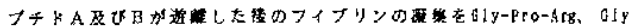

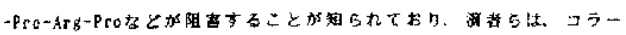

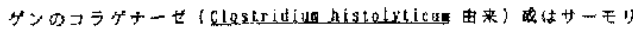

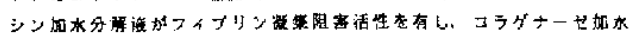

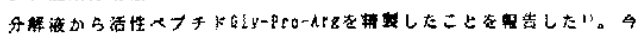

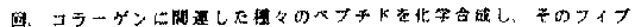

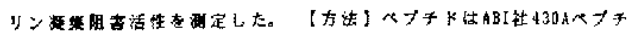

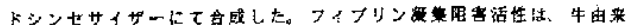

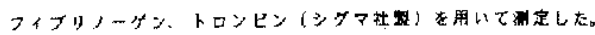

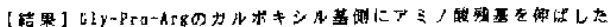

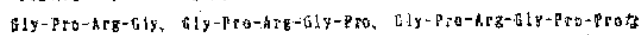

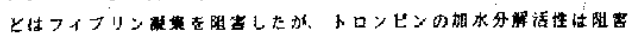
し名加力た。特にGLy-Pro-Arg-GLy-Pro-Prolt G

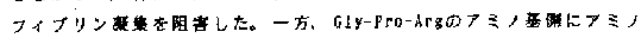

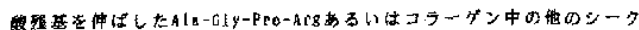

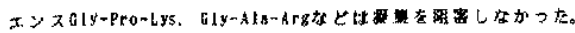

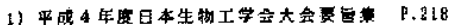

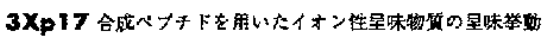

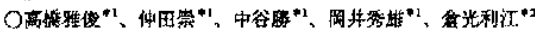

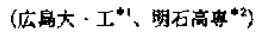

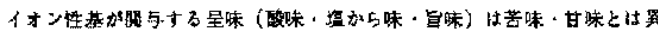

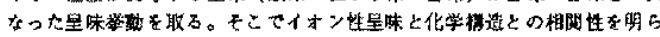

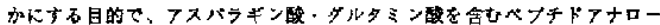

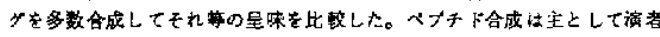

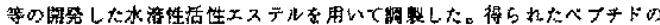

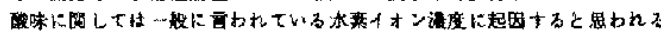

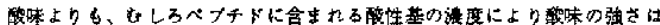
规定されることを融めた。大部分の酸往ベブチトのナトリウム坦は、NaC

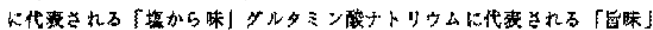

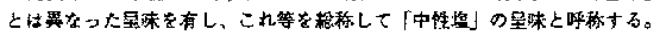

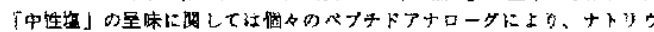

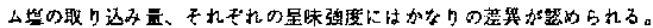

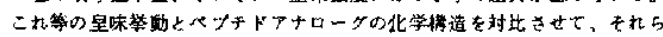

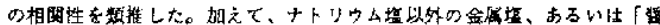
油」中でのキれぞれの「中性培」の呈味に与六了效果を比较した。

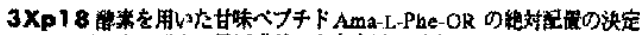

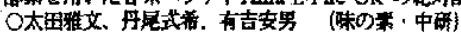

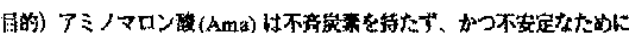

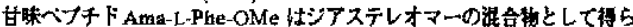

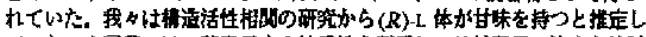

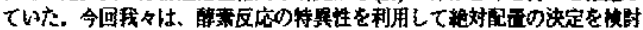
した。

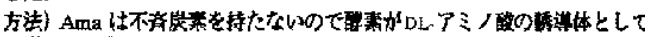

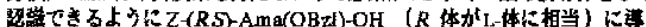

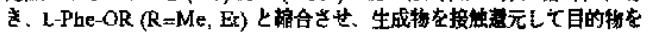
得度。

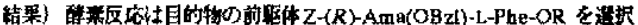

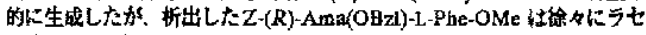

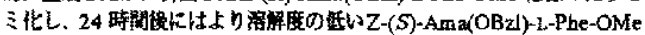

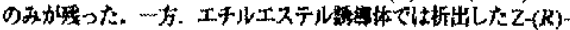

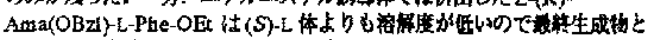

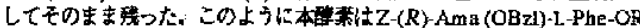

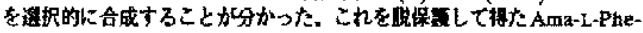

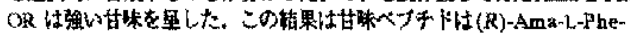

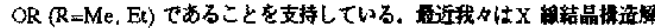

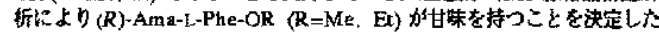
か、上眍の結果を支持している。

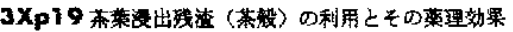

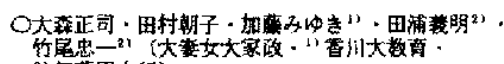

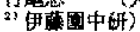

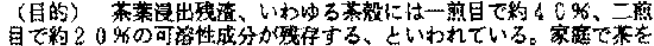

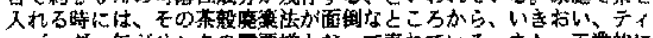

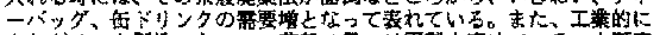

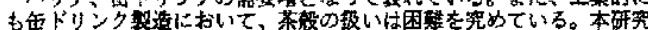

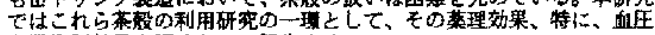

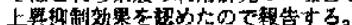

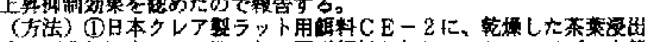

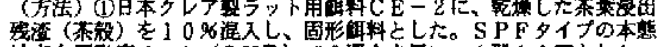

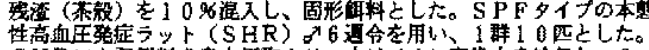

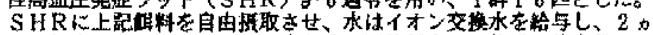

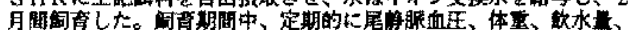

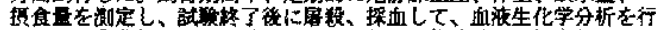

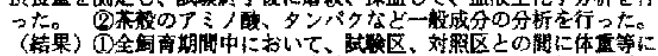

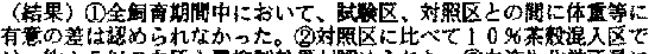

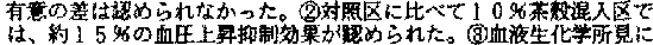

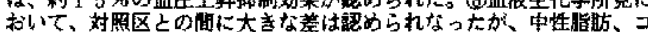
レステロールなどの减少する㥧向が示された。 


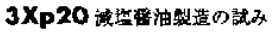

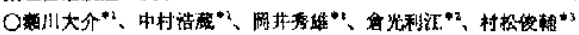

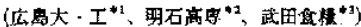

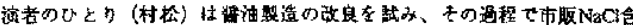

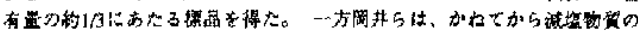

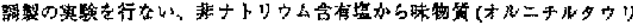

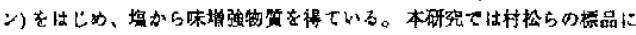

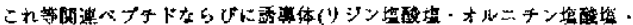

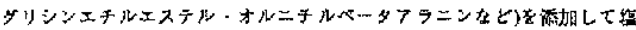

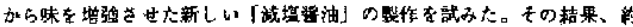

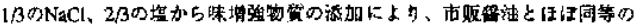

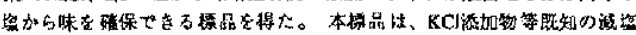

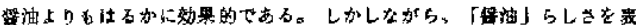
现するため结は、 $\mathrm{NaCl}$

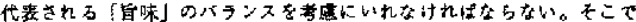

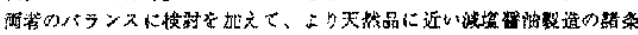
件を挨期した。

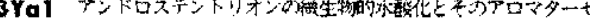 阴素"

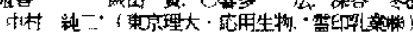

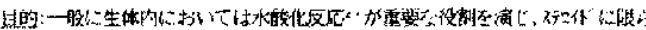

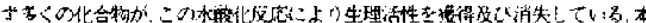

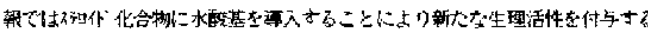
ことを試みた

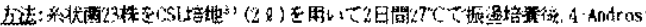

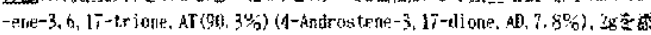

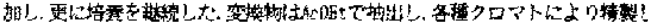

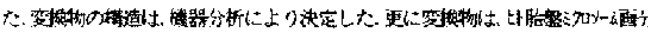

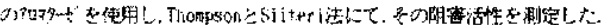

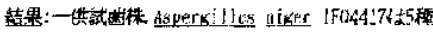

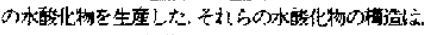
II : $12 \beta-$ - i

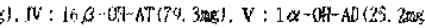

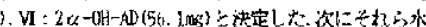

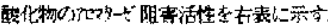

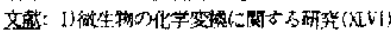

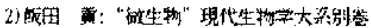

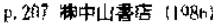

3)M lifa $\underline{\text { t }}$ al. : d. Ferment. Technology. ne. P. $3=$ (1) 1098

\begin{tabular}{|c|c|c|}
\hline \multirow{2}{*}{$\begin{array}{l}\text { 㤎 } \\
\text { 換 } \\
\text { 物 }\end{array}$} & \multicolumn{2}{|c|}{ Intribition(s) } \\
\hline & $1 \ln \mu n$ & 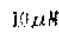 \\
\hline G & 13.3 & 2.4 \\
\hline III & 89.1 & $5 \hat{k} .7$ \\
\hline IV & 84.4. & 42.1 \\
\hline $\mathrm{V}$ & 89.17 & 2h. 8 \\
\hline
\end{tabular}

3 Ya2

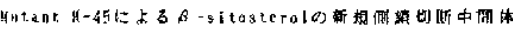

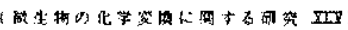

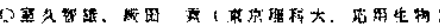

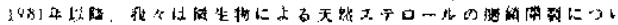

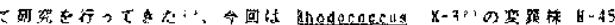

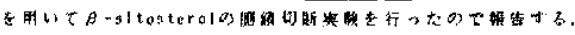

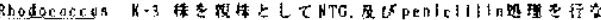

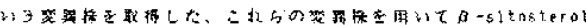

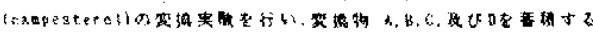

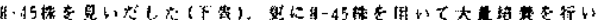

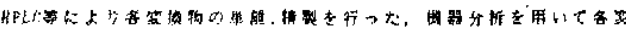

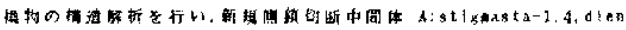

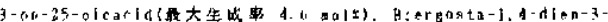

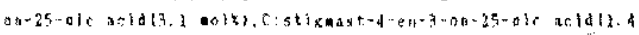

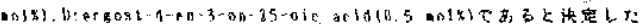

\begin{tabular}{|c|c|c|c|c|c|c|}
\hline \multirow[b]{2}{*}{ Stratns } & \multicolumn{6}{|c|}{ 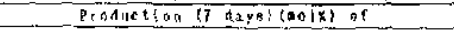 } \\
\hline & AD: & BNC & A & B) & c & p \\
\hline K-1) & 30.7 & 39.7 & - & $\cdots$ & - & - \\
\hline 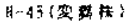 & 5. 1 & 21.7 & 4.6 & 3.1 & 1. 1 & 0.5 \\
\hline 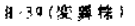 & 11.3 & 27.1 & ก. 8 & 0. $?$ & 0.6 & 0. 3 \\
\hline 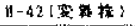 & 27.1 & 23.5 & $\cdots$ & - & 0.7 & a. 2 \\
\hline
\end{tabular}

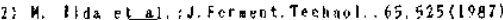

3 Yo3 2-Methylnaphthalene(MN)O2-Methyl-1-naphthol(MNO)

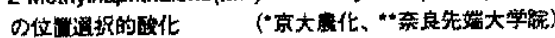

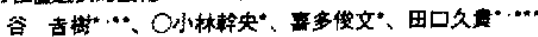

目的) Vitamin $K_{3}$ (menadione) は、現在、瞰料添加物なととして化 学合成法により生産されている。前報では、MNをmethylethyl ketone

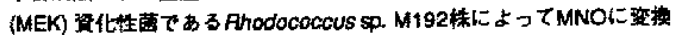

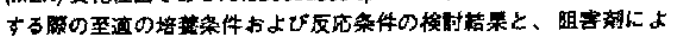

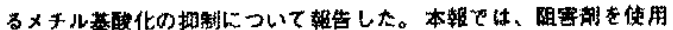

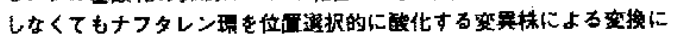
いて楥行した。

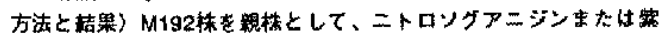

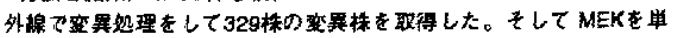

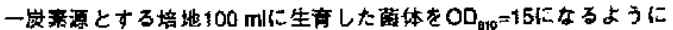

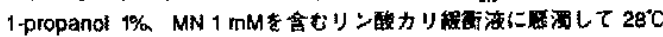

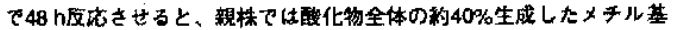

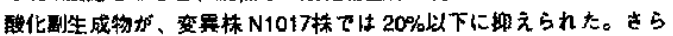
に、N1017株における至通な反条条件などについても䇉告する。 (“**現在、能工大应用微生物工学料)

微生物ブロセスによるメナジオン生産に封する研究(第了報)

\section{Ya4 デアセチル-7-アミノセファロスボラン政(D-7-ACA) から

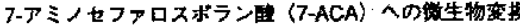

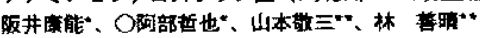

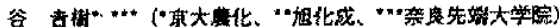

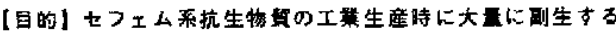
D-7-ACAラクトンを再利用するためのプロセス開発の一器として、エ

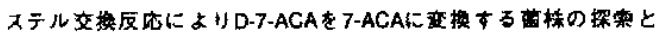

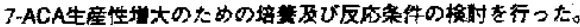

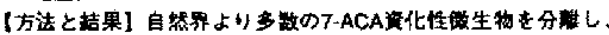

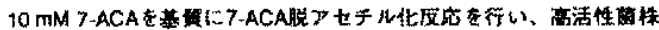

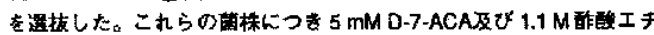
ルを基算としてD-7-ACAフセチル化反店を面い、亮生産性を有する菌

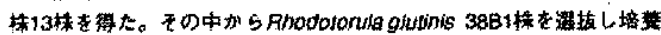

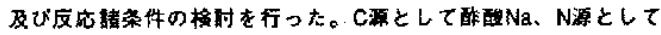

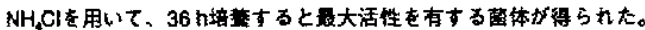

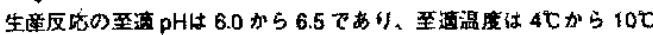

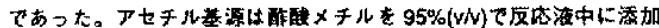

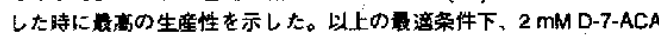

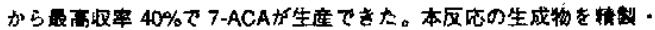

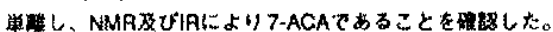

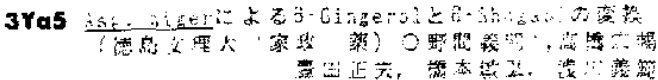

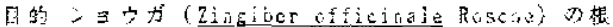

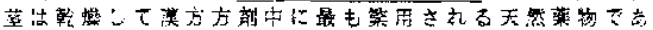

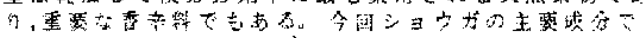

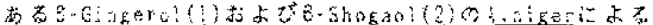

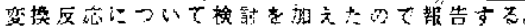

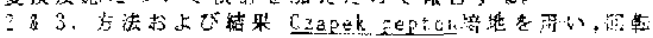

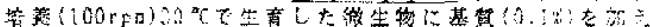

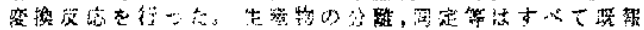

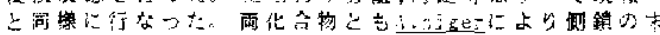

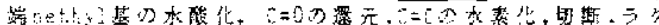

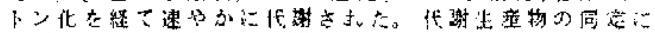

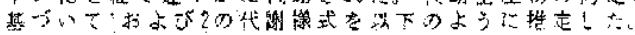

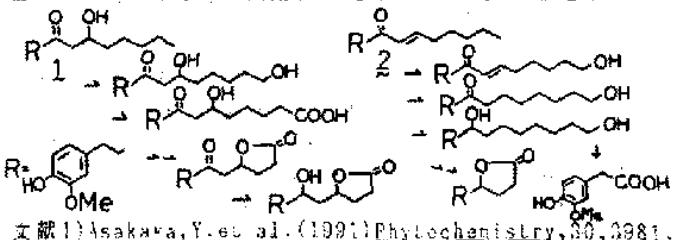

